\title{
Negotiating Muslim Women's Rights and Identity in American Diaspora Space: An Islamic Feminist Study of Kahf's The Girl in the Tangerine Scarf
}

\author{
*SURAIYA SULAIMAN ${ }^{1}$ \\ MOHAMMAD A. QUAYUM ${ }^{2}$ \\ NOR FARIDAH ABDUL MANAF ${ }^{2}$ \\ ${ }^{1}$ Western Languages Department, Faculty of Humanities and Social Sciences, \\ Prince of Songkla University, Pattani 94000,Thailand \\ ${ }^{2}$ Kuliyyah of Islamic Revealed Knowledge and Human Sciences, English Language and Literature \\ Department, International Islamic University Malaysia, 53100 Kuala Lumpur, Malaysia \\ *Corresponding author: ssuraiya1@gmail.com
}

Published online: 20 April 2018

To cite this article: Sulaiman, S., Quayum, M.A. and Abdul Manaf, N.F. 2018. Negotiating Muslim women's rights and identity in American diaspora space: An Islamic feminist study of Kahf's The Girl in the Tangerine Scarf. KEMANUSIAAN the Asian Journal of Humanities 25(1): 43-67, https://doi.org/10.21315/kajh2018.25.1.3

To link to this article: https://doi.org/10.21315/kajh2018.25.1.3

\begin{abstract}
This paper addresses the narrative of a Muslim woman who struggles to negotiate her rights, identity and sense of belonging in an American diaspora space. Despite the difficulties and obstacles of being regarded as an "other" in her adopted homeland, Khadra Shamy, the protagonist in Mohja Kahf's The Girl in the Tangerine Scarf, chooses to maintain her Islamic identity with a new interpretation of her faith while attempting to build a hybrid identity as an American Muslim. The narrative implies that not all Muslims interpret their religion in the same way and that Muslims identify themselves with Islam to differing degrees. Hence, the media and critics of Islam clearly distort social reality when they depict all Muslims as extremists and all Muslim women as abject individuals. In addition, the employment of Islamic feminism in the analysis of the novel is an approach that can help enhance our knowledge concerning problems connected to the patriarchy that are pertinent in many Muslim communities, including ones in the West. The diaspora space in America has become a platform for Muslim women to gain more freedom, particularly the freedom to negotiate their rights and identities and to reinterpret religious teachings in a new light, a freedom that they may not be able to achieve in some Muslim-majority countries.
\end{abstract}

Keywords and phrases: Muslim women's identities, women's rights, Islamic feminism, Muslim diaspora, American Muslim 


\section{Introduction}

The lack of knowledge of the teachings of Islam is one important problem underlying the misunderstandings, mistrust, and sometimes, feelings of animosity that some people have towards Islam. As part of this problem, misrepresentations of Muslim women, which are pervasive in the mainstream media, have aggravated the situation of Muslims who live in Western countries. Apart from media propaganda emphasising the depiction of ideologically deviant Muslims who are criminals and terrorists, the representations of Muslim men and women in many "bestselling" novels and memoirs are also problematic. Irene Donohoue Clyne $(2003,20)$ interrogates a set of literary works she terms "airport literature", which she defines as "popular paperback books frequently ... sold in airport book-shops". She contends that this kind of novel aims to entertain readers rather than provide them with correct knowledge of Islam. Therefore, these novels work in tandem with news and films to formulate public opinion concerning Muslims and Islam. Claire Chambers $(2013,77)$ also studies this type of novel and defines them as an "oppressed, kidnapped genre", which, she asserts, mainly describes "the abuse, forced marriage or kidnapping of the passive, oppressed Muslim female".

In contrast, in The Girl in the Tangerine Scarf (2007), Mohja Kahf portrays her female protagonists in a more positive light and allows her characters to negotiate their sense of belonging in the American diaspora space, through either Islamic jurisprudence or a more dialectic approach to Islamic doctrine. Therefore, by reading Kahf's novel through the lenses of Islam and Islamic feminism, this paper provides access to myriad aspects of the faith and of Muslims, especially those who live in America. In addition, the experiences of women's rights that Khadra, the protagonist of the novel, gains from her visits to Muslim countries, such as Saudi Arabia and Syria, make her realise that in America, she can negotiate her Muslim identity and gain her rights as a Muslim woman under the protection of the law. However, from the novel, we can see that women in some Muslim-majority countries still have to fight for their rights, some of which have been violated by their own governments. Thus, the narrative implies that it is crucial for Muslims who live in the diaspora to recognise that they have an obligation to contribute to their adopted country, where they have freedom and opportunities they may not have been able to obtain in their homelands.

\section{Background of the Author and the Critical Reception of the Novel}

Mohja Kahf graduated with a PhD in comparative literature from Rutgers University and is currently a professor in comparative literature at the University of Arkansas, Fayetteville. She is mainly known as an Arab-American or Syrian-American poet 
and academic. She was born in Damascus, Syria, in 1967 and migrated to America in 1971. Her first book of poetry, E-mails from Scheherazad (2003), was a finalist for the 2004 Paterson Poetry Prize. Her novel, The Girl in the Tangerine Scarf, was chosen as the Booksense Reading Group Favourite for June 2007. In 2008, the novel was chosen as a book of the year for the One Book, One Bloomington Series by the Bloomington Arts Council, Monroe County Public Library, Bloomington, Indiana (www.poemhunter.com/mohja-kahf/biography/). The novel also ranked third among the "14 Novels about Muslim Life that Shouldn't be Missed", a book review by Ahmed Ali Akbar (2015), written for the well-known website, Buzzfeed. Kahf has published extensively in the creative arts, mainly poetry. She has also published numerous academic works, including, Western Representation of the Muslim Woman: From Termagant to Odalisque (1999).

Kahf's debut novel, The Girl in the Tangerine Scarf (2007), received positive feedback from critics and has been analysed in academic journals, book chapters, and several book reviews. In an article in The New York Times, Neil Macfarquhar (2007) states that The Girl in the Tangerine Scarf turns Kahf into an inspiring figure for young Muslim-American women who struggle to reconcile their faith with a society permeated by hostility. He also contends that the work helps build a bridge of understanding between Muslims in America and the general American public and that it allows Muslims, especially women, to express their views and invite the larger society to learn about Muslim issues from a humanistic perspective (Macfarquhar 2007). Allison L. Bear and Jacqueline N. Glasgow (2010), in "Negotiating Understanding through the Young Adult Literature of Muslim Culture", praise Kahf's novel as a strong voice challenging simplistic perceptions about the Middle East, Muslim women, and Arab Americans. Sirène Harb asserts that Kahf's text is a contribution from a "critically recuperative voice" exposing "the ambivalence of the location of Arab Americans in the United States" (2012, 14). She says the book also acts as a negotiating strategy of belonging for diasporic Muslims in America.

Concerning the idea of belonging and unbelonging, Ruzy Suliza Hashim and Nor Faridah Abdul Manaf (2009), in "Notions of Home for Diasporic Muslim Women Writers", compare Kahf's The Girl in the Tangerine Scarf with Azar Nafisi's Reading Lolita in Tehran (2003). The article focuses on how Muslim women writers who live in diaspora in America employ creative writing to represent their notions about their lost homelands and to describe their struggles with feelings of ambivalence and their criticisms of both their home countries and their host land (Hashim and Abdul Manaf 2009, 545). The authors assert that even though Kahf's notion of home in America is "full of complexities and clashes of cultures", the possibility remains that Muslims in the West can lead a normal life and resettle in 
their new homes. The authors conclude that Kahf's novel is "a positive book on transnationalism and integration" (Hashim and Abdul Manaf 2009, 552-554).

Firouzeh Ameri's PhD dissertation, "Veiled Experiences: Rewriting Women's Identities and Experiences in Contemporary Muslim Fictions in English", is an in-depth analysis of writings about Muslim women's identities and their veiling experiences. Ameri uses Kahf's The Girl in the Tangerine Scarf as one of her five sample texts. She suggests that these novels represent "the lives and religious identity of Muslim women who are neither victims nor escapees of Islam but willingly committed to their faith", portrayals that contradict the persistent image of Muslim women as either "victims or fortunate survivors" of a "backward" and "violent" religion (Ameri 2012, iii). Ameri cites Kahf's novel as a vivid example of Muslim women's writing that attempts to undermine "the condemnation of othering and stereotyping of Muslims" (Ameri 2012, iii).

Susan Taha Alkarawi and Ida Baizura Bahar's article, "Negotiating Liminal Identities in Mohja Kahf's The Girl in the Tangerine Scarf" (2013), also focuses on the notion of Muslim women's identity and the expression of their identity through the veil or headscarf. They hold a similar view to Ameri's that indeed, Kahf's novel helps demystify the persistent notion of Muslim women as "submissive or backward" (Alkarawi and Bahar 2013, 101). The article emphasises how the novel depicts the daunting experiences of a Muslim woman who insists on expressing her Muslim identity by keeping herself veiled.

The analyses of Kahf's novel as presented in these examples represent longstanding issues of Muslim diasporic experience in the West. However, no critic has applied an Islamic feminist approach to their reading of the novel. Thus, this paper investigates the lives of the protagonist and other characters in the novel by using the approach of Islamic feminism. In doing so, this paper provides an alternative view of the novel from the angle of Muslim women who stand up for their rights within the framework of Islamic teachings. The approach of Islamic feminism also enables an exploration of how this religious upbringing shaped the lives of the protagonist and some of the other female characters and how the context of diaspora allows them to reinterpret Islam in a new light. By employing an Islamic feminist discourse, we can discern the author's criticism of some Muslim religious practices, especially those that are dominated by a system of patriarchy, which includes the abuse of women's rights in Islam and is a hindrance to progress in Muslim society. This approach is meant to provide a well-rounded perspective to the novel, which does not present Islam in a defensive manner but rather encourages self-criticism, a notion that is still lacking in many Muslim societies, including in many Muslim diasporic communities. 


\section{Theoretical Framework: Islamic Feminism}

This paper's employment of Islamic feminist discourse helps fill the gap in secular feminists' criticisms of Islam. These criticisms are not based on teachings of the faith and lead to several grave misperceptions about Muslim women and the doctrines that shape their lives. Chandra Talpade Mohanty $(1994,197)$ states that "First World" feminists have a tendency to "colonize the material and heterogeneities of the lives of women in the third world", thus "producing/ representing a composite, singular "third world woman"". Mohanty contends that one example of this pitfall of First World feminist discourse is the generalisation of Islamic veiling as an act that violates basic human rights, regardless of differences in cultural and ideological contexts (Mohanty 1994, 209). Gayatri Chakravorty Spivak also remarks that "First World Feminists" have no authority to speak on behalf of women in the "Third World" [Spivak (1987) as cited in McLeod (2000, 184)]. Along this same line of thought, Islamic feminism can be seen as providing an alternative approach that can help Muslim women to grapple with problems of representation and generalisation. This is because Islamic feminism is the work of Muslim women themselves, whether academics or activists, who try to provide their Muslim sisters with appropriate ways to counteract simplistic views of Islam.

Margot Badran $(2002,1)$, in "Islamic Feminism: What's in a Name?" clarifies that the term "Islamic feminism" refers to "a feminist discourse and practice articulated within an Islamic paradigm", using the Quran and the teachings of the Prophet as its sources. In doing so, Islamic feminism helps Muslim men and women to achieve "rights and justice" (Badran 2002, 1) as highlighted in the Quran: "If any do deeds of righteousness - be they male or female - and have faith, they will enter Heaven, and not the least injustice will be done to them" (Quran, al-Nisa', 124; see also Quran, ali-Imran, 195). Leila Ahmed (1992, 64-65), a renowned EgyptianAmerican feminist scholar, also provides an insightful argument concerning the egalitarian conception of gender inherent in the ethical vision of Islam by giving evidence from the Quran and the hadiths. She cites the Quran, surah al-Ahzab, verse 35, which, in her opinion, illustrates the balanced virtues and ethical qualities, as well as concomitant rewards, for both male and female believers. God states: "For Muslim men and women, for believing men and women ... For men and women who are patient and constant, for men and women who humble themselves, for men and women who give charity ... For them has God prepared forgiveness and a great reward" (Quran, al-Ahzab, 35). This passage, according to Ahmed, is "a clear statement about the absolute identity of the human moral condition and the common and identical spiritual and moral obligations placed on all individuals regardless of sex" (Ahmed 1992, 65). 
Furthermore, Badran (2002) highlights that the reading of the Quran and hadiths, along with the adoption of the methodologies of ijtihad - an independent examination of religious sources - and tafsir - the main interpretation of the Quran - are the primary approaches of Islamic feminism. Along with these methodologies are methods from linguistics, history, literary criticism, sociology, anthropology, and other fields (Badran 2002). By adopting these approaches, women's rights, which have been granted to women since the inception of Islam but have been taken away because of historical circumstances, will be restored. Badran stressed, in an interview with Azza Basaruddin (2005), that Islamic feminism affirms the rights that Islam grants to women and the gender equality and social justice enshrined in the Quran. This confirms that Islam and feminism are not mutually exclusive but rather that "(rights-depriving) patriarchy and Islam are mutually exclusive" (Basaruddin 2005, 58).

Asma Barlas, a distinguished scholar in political science, also advocates a womenfriendly approach to Islamic teachings. She has emphasised the egalitarian characteristic of the Quran as follows:

The Qur'an's message of equality resonated in the teaching that women and men who have been created from a single self and are each other's guides have the mutual obligation to enjoin what is right and forbid what is wrong (Barlas 2012, 1).

Therefore, this new approach to the Quran, which is more gender-sensitive and women-friendly, serves to unite several issues concerning the rights of Muslim women. Barlas discusses in "Muslim Women and Sexual Oppression: Reading Liberation from the Qur'an" (2001) how a discourse of gender equality and social justice as advocated by Islamic feminism helps Muslim women realise the rights provided for them in the Quran. She argues that while there is a tendency for Muslims to "read sexual inequality, oppression, and patriarchy into the Quran", the Quran can clearly be read as "an antipatriarchal text, that is, as undermining the fundamental claims of patriarchy" (Barlas 2001, 118, italics in the text). She also asserts that part of the problem of gender inequality and social injustice in Muslim societies is the problem of how Muslims "fail" to read the Quran (Barlas 2001, 118).

However, that the rights of women are abused in many Muslim societies tells us that the teachings of Islam are not fully implemented in many parts of the socalled Muslim world. This abuse also underscores the vital roles of Muslim women's movements within Islam, for instance, the Arab women writers and Islamic scholars who have tried to express themselves on personal and political levels (Cooke 2001). These women distinguish themselves from Western 
feminists in that while Western feminists treat religions as their enemies, "Muslim women view the teaching of Islam as their best friend and supporter" (al-Faruqi 1988, 29). Badran (2009) also highlights that in contrast to feminism in the West, which is articulated outside of religious frameworks, Muslim women have explicitly and implicitly integrated religious teachings into the formation of their feminisms.

The aim of Islamic feminism is to allow Muslim women enough space to negotiate their own identities and express their independent existences as manifested in the Quran: "O Mankind! Be conscious of your Sustainer, who has created you out of one living entity, and out of it created its mate, and out of the two spread abroad a multitude of men and women" (Quran, al-Nisa', 1). This position also makes manifest that women have been granted dignity, humanity, and partnership with men by Allah and by the Prophet, who confirms the status of women in Islam by stating that "women are partners of men" (Naseef 1999, vii). This is because women represent and constitute half of humanity and share with their male counterparts the burdens of building a human society with work and responsibilities. Therefore, women are essential elements in the progress and prosperity of nations (Naseef 1999). Moreover, Islamic feminism makes women realise their potential since they are encouraged to revisit the history of Islam and learn how Muslim women have actively contributed to society. Academic research showcases that Muslim women have been significant contributors to the course of Islam since its inception, whether as religious scholars, social workers, or even ardent fighters on the battlefield (al-Faruqi 1988, 6-10; Mernissi 2005, 43-44; Khan 2012, 7).

Another justification of Islamic feminism as a discourse to understand Muslim women is its pragmatic approach. Ramadan $(2004,139)$ makes a cogent remark concerning the apparent incompatibility between Islamic ideology and social reality. He states that "to believe that nothing in the message of Islam justifies discrimination against women is one thing; to say that they do not suffer any discrimination in ... Muslim communities is another". It is also noteworthy that in human societies generally, women tend to achieve greater equality in secular spaces than in religious spaces. Muslim women find themselves treated equally in larger national or secular societies, while, unfortunately, they are hindered from gaining gender equality in their own communities (Badran 2006, 1). Part of this problem might come from the systems of patriarchy inherent in many Muslimmajority societies. The Quran highlights issues surrounding women's rights and their well-being, as these are clear indicators of the advancement of society. For this reason, Badran $(2006,1)$ underscores the role of Islamic feminism as being twofold: "to expose and eradicate patriarchal ideas and practices glossed as Islamic [that have been] 'naturalised' and perpetuated in that guise ... and to recuperate 
Islam's core idea of gender equality [which is] indivisible from human equality". Therefore, it is essential that Muslims confront reality, be pragmatic, and return to the Quran and hadith as sources for their actions and beliefs. In doing so, they will discover that there is a "broad scope for interpretations" on the teachings of Islam concerning women's issues and that "some people, either knowingly or not, have reduced it" (Ramadan 2004, 140). Thus, Islamic feminism, with its agenda to seek justice for Muslim women, can be considered an effective tool that can be used to disentangle many problems facing Muslim women.

Advocates for Islamic feminism reject the notion that the term "Islamic feminism" is an oxymoron. Badran (2009) asserts that Islamic feminism is not derivative; rather, it emerged in the global umma by promoting a new discourse within the religious paradigm. It not only concerns societal reform, but also seeks a fundamental transformation to achieve an egalitarian approach to religious practices. Miriam Cooke (2001) wrote an insightful book of literary criticism, titled, Women Claim Islam: Creating Islamic Feminism through Literature, adopting an Islamic feminist discourse as her approach. She stated that by working within the Islamic paradigm, Islamic feminism is actually an expansion and not a rejection of the faith (Cooke 2001, 61). Cooke also emphasised that Islamic feminism is not a "coherent identity". It is a strategic approach rather than an ideology, encompassing "a new, complex self-positioning that celebrates multiple belongings" (Cooke 2001, 59). By doing so, some women scholars have challenged conventional histories and canonical texts that "either omit mention of women or stigmatize their prominence as aberration" (Cooke 2001, 62). For this reason, Islamic feminism can be a beneficial approach for women in diaspora to negotiate their space in effective ways.

Additionally, Badran (2002) posits that one predicament in the life of Muslim women in Western diaspora is that second-generation Muslim women are trapped between the traditions of their parents' home countries in the Middle East or South Asia and their current practices. For example, the cultural practices of Muslim families, such as forced marriage and honor-killing that are present in some Muslim societies (Kordvani 2002), are still in practice among Muslims in diaspora. Everyday issues, such as entering a mosque or even women's right to education, are still part of Muslim diasporic community debates because of the confusion between cultural practices and the teachings of Islam (Ramadan 2004, 139). Therefore, Islamic feminism helps women untangle their parents' patriarchal ideology - an intrinsic part of their original cultures - and their culturally based religious practices. This is because Islamic feminism provides women in diaspora with Islamic interpretations that aim to fulfil their rights and potential (Badran 2002; Ramadan 2004). For example, some female Muslim characters in Kahf's 
novel demonstrate how they are economically independent and, at the same time, can be strong spiritual supporters for their family members. Thus, these women can realise their potential without forsaking their faith (Ramadan 2004, 142).

In consequence, by adopting Islamic feminist discourse in the reading of literary texts, this paper illustrates how the problems of gender inequality and injustice in Muslim societies are, in some cases, caused by Muslims' patriarchal approach to the Quran and other religious texts. Barlas $(2001,118)$ highlights that part of the problem of gender inequality and social injustice in Muslim societies is the problem of Muslims' failure to read the Quran and the influence of their patriarchal system in the interpretation of religious texts. As a result, she suggests, Muslims need to reread the Quran and reinterpret the Sunnah of the Prophet in light of their contemporary contexts and distinguish between the teachings of Islam and the impact that a predominantly patriarchal culture might have on Muslim societies, which leads to the misery of Muslim women in these societies. Thus, rereading the Quran and the hadiths, the texts that record the teachings of the Prophet, from an Islamic feminist approach, one discovers a "broad scope for interpretation" of the teachings of Islam concerning women's issues, which have been intentionally or unintentionally narrowed down (Ramadan 2004, 140).

Accordingly, the plights of diasporic Muslim women depicted in Kahf's novel highlight a pressing need for religious scholars in Muslim societies to introduce a more creative interpretation of Islamic teachings to help alleviate the suffering and improve the living conditions of Muslim women. This is because some Muslim women still suffer from patriarchal practices in their communities, despite being born and brought up as permanent residents and possibly citizens of their surrogate countries in the Western world.

\section{The Girl in the Tangerine Scarf: A Brief Summary}

The novel is a bildungsroman, or a coming-of-age story, told from Khadra Shamy's point of view. The narrative follows the trajectory of Khadra's life as well as her psychological, moral, and intellectual development from her youth to adulthood. Kahf locates Khadra's birth in Syria, but she was raised in America. She moved with her family - mother, father and a brother - to America during her preschool years and grows up in a pious Muslim family in a tightly knit Muslim community in Indiana in the 1970s. During her childhood and college years, Khadra learns to adjust herself to American society and undergoes different phases of selfdiscovery and religious understanding. While pursuing her first college degree, Khadra faces a tough time in her married life. She decides to get a divorce, has an abortion and flees to Syria, her ancestors' home country. It is the first time she feels 
detached from her family, her Muslim community and God. However, in Syria, Khadra adopts a new outlook on life that allows her to become more perceptive of different beliefs and cultures. Upon her return to America, Khadra's intellectual and spiritual growth leads her to adopt a more balanced life, allowing her to live more comfortably in her surrogate country. As a result, she proudly embraces her hybrid identity as an American Muslim.

The following sections analyse the behaviour of Khadra Shamy, the protagonist in Mohja Kahf's novel, The Girl in the Tangerine Scarf, and her life experience in her surrogate country. Through Khadra, the narrative reflects the experience of a woman who tries to negotiate a hybrid identity in the American diaspora space. The narrative is concerned with the quest for women's rights in the American context in comparison with women's rights in Muslim-majority countries. In addition, the development in the protagonist's life showcases how a Muslim woman in America formulates her identity and how the narrative debunks some negative stereotypes of Muslim women. The analysis also sheds light on a dialectic view of Islamic teachings concerning the practices of Muslim women, such as ideas about divorce and hijab, a Muslim woman's headscarf.

\section{Negotiating Muslim Women's Rights and Identity in American Society}

While the novel depicts racial prejudices and harassment from white nationalists and religious bigots, readers are also introduced to many beautiful aspects of America and learn how Muslim immigrants find solace from open-minded and caring American people. Therefore, one of the main points in the novel is Khadra's development of her identity and her relationships with Muslim and non-Muslim friends in her surrogate country. By the end of the novel, she becomes more mature regarding her life' experiences, more stable in the matter of her identity, and more independent in terms of her religious understanding.

Self-criticism is another pivotal characteristic of the novel. The narrative exposes hypocrisy and contradiction, especially concerning the treatment of women, in Muslim communities. The narrative presents this as one of the biggest challenges for members of Muslim diasporic communities in the West, many of whom are descendants of immigrants from conservative and patriarchal societies in the Middle East, Africa and South Asia. The novel highlights the demand of Muslim women to voice their opinions so they can enter an area of discussion that was previously closed to them (Cooke 2001). The narrative engages in debates on identity conflict and some of the patriarchal treatment encountered by the protagonist. The novel also highlights a controversial issue regarding Khadra's adoption of ijtihad, when she decides to have an abortion by reasoning that Islam allows women the right 
to abortion within 120 days of pregnancy (Kahf 2007, 244-245). This notion of ijtihad, according to Islamic feminist scholars, is an independent examination of religious sources based on an individual's substantial knowledge of religion when a legal tradition is not clear and available (Badran 2009; Cooke 2001). Cooke (2001) refers to Abdullahi an-Na'im, a renowned scholar of Islamic law, who emphasises that Islamic rules and laws are not top-down and static. In contrast, they are "democratic, emerging out of a community consensus that derives from individual understandings of God's laws without privileging the identity and status of the individual interpreter" (62). Accordingly, we can see in the novel how Khadra tries to advocate the right of an individual to assert one's own understanding of religious rules, even though it may lead to controversy. This point will be discussed in detail in the section concerning a dialectic view of Islamic teachings.

\section{A Quest for Women's Rights in the American Context and in Muslim-Majority Countries}

While the novel demonstrates a positive perspective of America and encourages cultural dialogues between Muslims and non-Muslims, it also raises issues regarding racial discrimination and Islamophobia, which have a significant impact on the lives of Muslim women in America. Khadra's experiences of racial prejudice and religious bigotry are excellent examples of how Muslim women become victims of the animosity towards Islam. Khadra faces daunting experiences on several occasions, especially at school. One bitter incident occurs when her male schoolmates call her "raghead" and tell her to take off "the towel" (Kahf $2007,124)$, the terms they use to denigrate Khadra's way of being an observant Muslim by wearing her hijab, a Muslim headscarf. This incident clearly illustrates the ordeal some Muslim female students have to go through in American schools.

The murder of Zuhura, Khadra's older Muslim friend, who lives in the same community, also suggests the undercurrent of racism and Islamophobia in American society, even before 9/11. Zuhura is an active and articulate college student. Her father is a white American convert, and her mother is an African Muslim from Kenya. People at the Dawah Center, the religious centre of the community where Zuhura and Khadra belong, believe that Zuhura was raped and killed by members of the Ku Klux Klan, a group of racists and white nationalists, while she was driving back home from college at night. One critical aspect of this tragic incident is the reaction of the people at the Dawah Center. It is to be expected that the media coverage about Zuhura's murder is full of bias. Additionally, instead of searching for the murderer, the police accuse Luqman, Zuhura's fiancé, of honor-killing and deport him on a technical visa violation. However, the narrative also exposes the sexist attitudes of the people at the Dawah Center, who seem to agree that "she 
should not have been traipsing about the highway at midnight alone", that "she has been asking for trouble", and that "the family should've given her more guidance. You [should have] protected your daughter, [they proclaim]" (Kahf 2007, 94-95).

This murder case and the previously noted sexist remarks strongly indicate an abuse of Muslim women's rights. It is evident that Muslim women encounter prejudice not only from outsiders but also from within the Muslim community. Therefore, advocates of Islamic feminism are correct when they suggest that Islamic doctrines may support women's rights, but a so-called "Islamic" community may hinder them from the rights granted in the Quran (Badran 2006; Cooke 2001; Ramadan 2004).

Apart from the aforementioned incidents, Khadra also encounters prejudice in patriarchal and authoritarian "Muslim" societies. One of the most eye-opening experiences for her occurs during her Hajj pilgrimage, in which she travels with her family to Saudi Arabia. Here, Khadra confronts prejudice against women when a few religious policemen, matawwa, detain her and cause her to feel embarrassed because she has mistakenly gone to the mosque adjacent to the place she is staying to perform a prayer. It might be Khadra's own fault that she does not learn in advance about the practice in Saudi Arabia, where women are not allowed to pray at mosques. In America, the mosque is not only her place of worship, but it was also her Sunday school and playground when she was young. Khadra finds this incident bewildering because it is a distortion of Islamic teachings and of the practices of the Prophet and his female followers. After her detention, Khadra brings up the issue with her parents concerning women's rights and their relation to the mosque:

Women have always gone to the mosque. It's part of Islam. [...] What about Aisha? What about how Omar wished his wife would not go to the mosque for fajr but he couldn't stop her because he knew it was her right? What about the Prophet saying 'You must never prevent the female servant of God from attending the houses of God?' I told the matawwa that hadith and he laughed - he laughed at me, and said 'listen to this woman quoting scriptures at us!' (Kahf 2007, 168, italics in the text).

Despite the bitter experience, Khadra's knowledge of the teachings of Islam confirms her understanding that it is not Islam but rather a patriarchal norm that hinders Muslim women from achieving the rights fully granted to them by God (Badran 2002; Barlas 2002; Cooke 2001). This incident implies that certain aspects of Islamic teachings have been distorted by some abusive power in society, and this issue should be addressed. 
In addition to the incidents in America and Saudi Arabia, another side of Muslim women's tribulations is revealed to Khadra on her visit to Syria, where she learns from her aunt about the sufferings of Muslim women under the Baathist regime. Khadra's aunt recalls the situation in which Muslim women were forced by the state police to take off their hijabs while walking in the street. She tells Khadra that on September 28, 1982, the government dropped a thousand female paratroopers over Damascus, with a male backup soldier behind each of them. They blocked off a section of the city and grabbed any woman who was wearing a hijab. Khadra's cousin, Reem, was stripped of her hijab, and at gunpoint, her jilbab (a long, loosefitting garment) was ripped off by a paratrooper who set it on fire and left her half-naked. Later, she was found huddled in the alley of an apartment building, traumatised and disoriented. This incident caused Reem's father to have a heart attack (Kahf 2007, 280-282). In a book titled, The Veil: Women Writers on Its History, Lore and Politics (2008), Kahf again reveals the traumatic history of the forced unveiling of women in many Muslim countries in the 20th century, which went unnoticed by Western feminist scholars and the media alike (Kahf 2008, 3136). The incidents of forced unveiling portrayed in the novel are reflections of the real situation occurring in Syria in 1982 (Kahf 2008, 34-35).

At this point, it is evident that the prejudice and discrimination Khadra has experienced in America, Saudi Arabia and Syria, illustrate the plight of Muslim women who are at the receiving end of all forms of prejudice. They face harassment from biased people in Western society and even from those who perceive themselves to be "pious" Muslims. It is clear that the issues of discrimination against women and the suppression of women's rights do not occur only in Muslim countries, as usually depicted by the Western media. Some Westerners, who see themselves as the saviours of Muslim women, also fail to fulfil their so-called "white man's burden", the colonising ideology in which white colonisers believe they must "civilise" their colonised subjects (Oxforddictionaries.com). Worse still, Western society becomes a platform for haters of Muslim women to demonstrate discrimination against Muslim women. Ironically, the negative image of the veil depicted by the Western media has been used by some Westerners to manipulate and oppress Muslim women (Alkarawi and Bahar 2013).

Nonetheless, one crucial difference exists between Khadra's experiences in America and Saudi Arabia. While Muslim women in America go through difficulties caused by racist individuals, this discrimination is not the result of state initiative. It is actually against the law of the country. In contrast, discrimination against women's rights in Saudi Arabia is endorsed by the law of the country itself. In this regard, Muhammad Abduh, a renowned Egyptian scholar of the 19th century, and Tariq Ramadan, one of the most distinguished Islamic scholars of the 21 st century, are 
right when they opine that some non-Muslim countries are more Islamic than some Muslim-majority countries (Hasan 2011; Ramadan 2004). We think that this is a crucial message of the novel, as it is salient for Muslim diasporas in the West to appreciate the freedom they are granted in their surrogate countries and to try their best to contribute to the country they now consider their home. In doing so, they can help to encourage mutual trust and respect between Muslims and their fellow human beings. This will eventually result in a more peaceful coexistence.

\section{The Formulation of Muslim Women's Identity and the Deconstruction of Pertinent Stereotypes}

One important message in the novel concerns the formation of Muslim women's identity and the subversion of the stereotypes of Muslim women ubiquitously represented in the mainstream media. These two issues are interconnected because Western people's perceptions of Muslim women's identities have been largely formulated by the Western media. Jusmin Zine $(2002,18)$ proposes that in the postcolonial world, the dominant portrayals of Muslim women by the hegemonic perspectives of the West are challenged by some non-Muslim feminist scholars and Muslim women, who destabilise the one-sided representation of Muslim women. The Girl in the Tangerine Scarf is one example of how a novel written by a Muslim female writer helps to decolonise "the epistemological spaces in which one comes to know of Islam and Muslims, and reclaim ... the space to name [her] own identities and realities" (Zine 2002, 19). Through the protagonist and other Muslim female characters in the novel, the narrative redefines the realities in Muslim women's lives and demystifies several myths about Islam and Muslim women.

In the novel, Khadra makes significant progress in her surrogate country. She gradually learns to adjust to a multicultural society and dares to dismantle some conventional beliefs about Islam that are introduced to her by her parents and teachers at the Dawah Center. Khadra's understanding of Islam and her worldview are gradually altered through her experiences, her exposure to different types of American Muslims and her interactions with non-Muslim friends. Moreover, the narrative depicts some alternative views about Muslim women. We see a different image of a Muslim woman from the cover of the novel and its title, The Girl in the Tangerine Scarf. It portrays a woman in a brightly coloured head scarf, a black top, and a pair of jeans, gazing confidently at readers from a defiant angle. This new portrayal of a Muslim woman can be read as a symbol of a new kind of Muslim woman that contradicts the Orientalist depiction of suppressed Muslim women presented in "airport literature" (Clyne 2003, 20) or in the "oppressed, kidnapped 
genre" (Chambers 2013, 77). The popular presentations of Muslim women on the covers of these novels are normally of women wearing mysterious black face veils, allowing only the eyes to be seen. The typical plot of this narrative presents Muslim women as escapees from the oppression of Muslim misogynists; they are eventually liberated by Western saviours, who are invariably male.

The narrative also helps debunk stereotypes of Muslim women by giving a strong voice to Muslim women; it introduces active women who are proud of their Islamic heritage, yet are sufficiently confident to venture into the unknown space of a border life of cultural amalgamation (Bhabha 1994). They are highly competitive and keen to take a leading role in society. Thus, the diverse depictions of Muslim women in the novel help enhance its readers' understanding of Muslim women's identities.

Apart from the protagonist, Ebtehaj, Khadra's mother, is also a woman of strong character. She is a conservative Muslim who adheres strictly to her meticulous approach to the rules of Islam, but she is far from being oppressed. In contrast, she is the one who has a say in the house, and her ideas are respected by her husband. She is a well-educated woman who dreams of becoming a doctor but has to sacrifice that dream for the sake of her family and missionary work at the Dawah Center. She educates her children using her scientific knowledge and her deep understanding of Islam. It is also noteworthy to state that Wajdi, her husband, is far from being a narrow-minded misogynist but rather is a caring and devoted father who helps his wife do chores, as shown by the example of the Prophet of Islam. He is a skillful dressmaker who makes beautiful, princess-like dresses for his daughter on several occasions, including her wedding. He encourages his daughter to study whatever field interests her and is willing to drive across state lines to take her to class. He works hard to send his son to medical school and even allows his younger son to establish an Islamic hip-hop band.

Teta, Khadra's grandmother, is a loving and modern Muslim woman who likes to sing to her grandchildren. She was among the first group of women in Syria who worked as operators, one of the few careers allowed for women during that time. Even though she was criticized by her neighbours for going out to work, it did not discourage her from seeking her own career path. Zuhura, Khadra's older friend who is murdered, is an articulate and confident woman. In college, she is known for being outspoken on issues of justice for her Muslim fellows. She is also an active member of her university's African Student Association. Hanifa, the sister of Hakim, Khadra's childhood friend, who grows up in the same community with Khadra, becomes the first Muslim woman to participate in a car-racing tournament. 
Last but not least, Khadra herself is an active and intelligent woman. At a young age, she and her friends are called by their Islamic teacher at the Dawah Center "how come" girls, for they never stop asking questions during Islamic lessons. Khadra grows up to be an inquisitive teenager eager to learn new things. In her teens, Khadra becomes obsessed with the idea of Islamic revolution and adopts a more serious and strict way of life, as expressed by her black hijab and sombre clothes. Nevertheless, when she develops an interest in the classical teachings of Islam, Khadra's personality becomes more balanced. It is evident that Khadra's understanding of Islam is not static. She does not adhere only to the understandings advocated by the Dawah Center. What she learns first is a stepping stone for her to seek more knowledge, and she never stops acquiring new understanding of her faith. Her knowledge of Islam develops as she becomes intellectually mature. She learns that Islamic rules can be approached from numerous angles; there are no fixed interpretations of Islam. Therefore, Khadra's view of other human beings, Muslims and non-Muslims alike, becomes more inclusive as she learns more about her own faith. Khadra's worldview also expands as she gains more experience of other people's lives in her college years. This kind of outlook later allows her to live an independent life.

The American diaspora space clearly allows Khadra to develop a sophisticated viewpoint. She learns how to negotiate her hybrid identity, and by doing so, Khadra demonstrates that it is possible to create a space in which hybrid identity can be formulated and cultural exchange can be initiated between Muslim diasporas and their host societies. Nonetheless, from our reading of the novel, we are aware that it may take time and much patience for human beings to embrace new knowledge and come to the realisation that we have a lot in common and that difference is a blessing to mankind.

\section{A Dialectic View of Islamic Teachings and the Metamorphosis of a Woman's Self}

The novel addresses several controversial aspects of religious teachings that are normally culture-related, for instance, the notion of women's rights, gender inequality and racial discrimination. These issues showcase that there are competing voices of religious interpretation among authorities within Islamic communities who "seek to represent themselves as the privileged readers of tradition or the bearer of 'true' Islam" (Mandaville 2001, 94). However, one distinguishing aspect of the novel is its criticism of a patriarchal system within Muslim communities. What we hear through Khadra is her attempt to apply the method of ijtihad, or her personal interpretation of Islamic rules, based on her extensive knowledge of the faith, especially in matters concerning women's rights and especially when she 
decides to have an abortion (Kahf 2007, 247-251) and to unveil in public (Kahf 2007, 309). These attempts can be considered an illustration of "the debates and negotiations over Muslim authenticity and authority", enriched by their experiences of diasporic life in a transnational scene (Mandaville 2001, 54). Concerning the notion of ijtihad, it is evident that Khadra bases her argument on the definition of ijtihad proposed by Islamic feminist scholars. For instance, Cooke (2001) contends that the Quran and the Sunnah are open to ijtihad, which she defines as "a technical term that refers to the process of independent reasoning that scholars and also non-scholars may choose when a legal precedent is not immediately clear and available" (Cooke 2001, 62, italics added). Thus, it is a crucial point that for Islamic feminist advocates, the right to ijtihad does not belong only to scholars or religious authorities but also to knowledgeable individuals who have a strong background in Islam.

Moreover, Khadra's personal accounts during important phases in her life reveal a dynamic life full of developments. Several incidents suggest a process of metamorphosis in terms of her ideas and identity, through which Khadra becomes a new woman. One of the most important stages starts with her marriage to Juma, a young man from Kuwait, who comes to America to pursue a degree in engineering. Unfortunately, their marriage does not last because of Juma's conservative ideas about Muslim women. According to his social upbringing, women are required to take care of all the household chores and are not allowed to even ride a bicycle. In contrast, Khadra grows up under the instruction of her teachers at the Dawah Center and her parents, who may appear conservative in many respects but are aware of women's rights in Islam. Khadra's problematic relationship with her husband starts when Juma requires Khadra to cook for him even though she is very busy with her assignments and exam papers (Kahf 2007, 240-243). They also argue over Khadra's cycling in the community to do grocery shopping, an act Juma considers to be infringing on the teachings of Islam (Kahf 2007, 227-230). When they finally divorce each other, Khadra determines that she is pregnant and decides to have an abortion, for she is not ready to become a mother while studying for her degree (Kahf 2007, 247-252).

The idea of abortion is another controversial issue in the novel. Khadra insists that her strong knowledge of Islamic jurisprudence allows her to conclude that women can have an abortion within the first 120 days of pregnancy, and she demands the right of ijtihad and her right over her body and life on this matter (Kahf 2007, 245). Kahf's standpoint explicitly reflects the argument proposed by Cooke (2001), an ardent advocate of Islamic feminism, in which she states that in this modern world of reproductive technology women are provided an opportunity to have control over their bodies. They also realise how "the biological specificity of their foetus- 
carrying bodies forces them to be dependent on men" (Cooke 2001, 64). As a result, the legitimacy of men's domination over women's lives becomes questionable, and men's status in relation to women needs to be redefined (Cooke 2001).

However, it is crucial to note that the issue of women's right to abortion is actually a controversial topic among Muslim scholars. Indeed, Khaled Abou El Fadl, one of the most renowned scholars of Islamic law, has given his legal opinion concerning women's right to abortion in Islam, which is available on the website, Scholar of the House. He maintains that the majority of Muslim scholars consider abortion to be unlawful except under very narrow circumstances, such as in the case of the health of the mother (El Fadl n.d.). The novel, however, suggests a different view on this issue. From Khadra's decision, it can be implied that the protagonist agrees with a minority group of scholars who allow abortion within 40 to 120 days because they consider the embryo to be endowed with a soul only after that period of time. Nonetheless, even among scholars who hold this view, abortion in that period is considered reprehensible and disfavoured, if not sinful (El Fadl n.d.). As a result, readers are introduced to one of the most controversial scenes in the novel, when Khadra, after her istikhara or consultation prayer, decides to have an abortion. It is thus evident that Khadra chooses quite a radical standpoint on the matter of abortion, and she insists on making her own decision without letting her husband exert control over her life and future. However, it may be difficult for many Muslims who have read this novel to agree with the protagonist on the matter of abortion. Consequently, this incident leaves Khadra in a miserable situation in which even her usually very supportive parents and siblings are indifferent to her. Heartbroken, Khadra stops praying, becomes detached from God and decides to travel to Syria to seek refuge in her forefathers' homeland.

From this phase of Khadra's life, it is obvious that one of the challenges facing Muslim women in a Western country, as presented in the novel, is how to balance their hybrid identities and negotiate the teachings of their religion. It is noteworthy that the narrative actually reflects the real situation in Muslim communities in the West concerning women's issues. In academia and the media, Muslim women have started to make their voices heard. These women are well-versed in Islamic jurisprudence, and hence, demand their rightful position in the circle of religious authorities in which male scholars were previously endowed. ${ }^{1}$ We also have observed more and more cases of Muslim women who advocate for women's rights to interpret Islamic doctrines from an egalitarian viewpoint. Furthermore, we have witnessed incidents such as Muslim women demanding their rights to pray at the mosque and lead prayers. ${ }^{2}$ This phenomenon shows the transformation of Muslim women in the diaspora, where the interaction of cultures becomes inevitable, and the need for Muslim diasporic communities in the West to find ways to handle this kind of change and challenge. 


\section{Hijab: An Alternative Approach}

The last but not least important topic of discussion in this paper is the issue of the hijab or Muslim headscarf. It is significant to note that there are several reasons for a Muslim woman to don the hijab. Some women adopt the hijab because they believe it to be the demand of God, while others may think of wearing a hijab as a demonstration of social solidarity or as resistance to the imperial power (AbdulGhafur 2005, 5). For example, Cooke (2001, xi) stipulates that during the period of the Islamic revolution, Muslim women in Iran adopted the veil "to demonstrate their anti-West nationalist conviction". However, it should also be acknowledged that there are many other women who don the hijab simply to follow their familial practice and community traditions (Abdul-Ghafur 2005).

The novel presents an alternative aspect of hijab that illustrates the way a Muslim woman attempts to negotiate her identity and belonging. While visiting her relatives in Syria, Khadra has another crucial development in her perceptions about hijab. Due to her religious upbringing, Khadra has strictly adhered to the idea of veiling. Nevertheless, in Syria, she unveils for the first time in public.

Khadra paused, ... The scarf was slipping off. The chiffon fell across her shoulders. She closed her eyes and let the sun shine through the thin skin of her eyelids, warm her body to the very core of her. She opened her eyes, and she knew deep in the place of yaqin that this was all right, a blessing on her shoulders. Alhamdu, alhamdulilah. The sunlight on her head was a gift from God. Gratitude filled her. ... Here, was an exposure, her soul an unmarked sheet shadowing into distinct shapes under the fluids. Fresh film. Her self, developing (Kahf 2007, 309, italics in the text).

Interestingly, the description of the scene suggests that the unveiling does not occur as a rebellion against God's command, nor as a denial of the teachings of Islam. In contrast, it comes from the realisation that God is too merciful to put a barrier between her and the sunshine that gently penetrates her skin and hair. It is also noteworthy that the symbolic scene of unveiling is not presented from a radical feminist perspective, which sees the hijab as a symbol of oppression.

On the one hand, there are arguments about the clarity or ambiguity of the Quran regarding veiling and unveiling, such as one suggesting that veiling is not compulsory since it was meant for the Prophet's wives, or that it is part of the Arab tradition, or that Allah told women to cover their bosom, not their head (Ahmed 1992). On the other hand, the majority of Muslim scholars treat veiling as compulsory because women's public dress code is mentioned in the Quran as khimar (head scarf) and 
jilbab (shawl or cloak) (Hasan 2011, 115). Some Muslim women also treat veiling as a spiritual centeredness and a response to the "hollowness of modernity, and the objectification of women in consumer capitalist culture" (Bullock 2011, 161). Nevertheless, some Muslim scholars apply the theory of maqasid al-shai'ah or higher objectives of Islamic law regarding the rule of hijab. They come to the conclusion that the law concerning women's head coverings should be interpreted based on a perfect balance between tradition and reason, meaning there can be a relaxation of legal rules in times of hardship. For instance, Abdullah b. Bayyah, a leading contemporary jurist, holds the view that Muslim women must cover their hair in public, but if the covering of the hair brings hardship, social exclusion, or physical harm to women, they are allowed to uncover their hair (Hasan 2011, 7576). In addition, modernist reformers such as Sir Sayyid Ahmad Khan of British India and the late Sheikh Zaki Badawi, former Imam and Khatib of the Regent's Park Mosque in London, propound that the requirement for Muslim women to cover the hair should no longer apply in modern societies, especially in Western countries, in which female hair does not generally cause sexual temptation as it becomes normal for women to appear in public without covering their hair (Hasan 2011, 75-76).

Therefore, when analysing Khadra's view on hijab, we can see the influence of those kinds of interpretations concerning Muslim veiling. In the novel, Khadra treats veiling and unveiling as the same process of enlightenment: "How veiling and unveiling are part of the same process, the same cycle, how both are necessary; how both light and dark are connected moments in the development of the soul in its darkroom" (Kahf 2007, 309). For Khadra, if veiling becomes a barrier between her and other human beings, then it is not the purpose of the veil. If veiling is meant for modesty, it is then more important for one to keep her modesty, and the veil becomes an extra piece of cloth that identifies her as a Muslim who upholds modesty. Additionally, if a veil is a tool to express one's identity, then unveiling becomes a process of giving up to the hegemonic thought of the West, which always defines the Muslim veil as a symbol of oppression. In this sense, veiling becomes a tool of dissidence, and Khadra chooses to keep herself veiled (Kahf 2007, 424-425). As asserted by Jennifer Heath (2008), it is apparent in today's world that the veil has become a symbol of resistance against ethnic and religious discrimination. "When the veil is forcibly stripped from its wearer, that too, is subjugation, not emancipation" (Heath 2008, 3).

Later in the novel, Khadra is more relaxed with her observance of the hijab; she wears it whenever she wants to express her identity and leaves it at home whenever she feels it is unnecessary for her. However, Khadra indicates that the veil and her occasional unveiling are not symbols of liberation, as understood by Western 
feminists. What is more important is that it is her personal choice to express her identity. In this sense, she chooses to maintain her sense of Islamic identity and her cultural heritage through the veil (Kahf 2007, 424). The veil, in consequence, does not represent the oppression of Muslim women, as generally understood by the Western public, but rather the empowering and enforcement of Muslim women's identity. In this regard, Kahf has challenged the misconception that for Muslim women to be fully integrated into American society, they are required to remove the hijab. Kahf creates a different narrative of diasporic Muslim women, which includes the hijab or Muslim headscarf as a demonstration of Muslim Americanness, rather than an indication of foreignness and otherness (Abdurraqib 2006).

\section{Conclusion}

A detailed analysis of the female characters in several contemporary novels reveals that the representations of Muslim women by the Western media, secular feminists, and right-wing politicians as oppressed, ignorant and backward are gravely problematic. The perspective of Islamic feminism deployed by the novel and in this paper leads us to conclude that the media and critics of Islam need a subtler approach for their study of Muslim women. The novel proves that one cannot lump Muslim women into a simplistic stereotype, as usually presented in the media, shallow types of literature, and entertainment, and biased pieces of so-called academic work. The protagonist, Khadra, is a distinct illustration of how Muslim women have significantly contributed to "the negotiation of what it means to be Muslim in the American context" (Haddad, Smith and Moore 2006, v). Khadra and many other female characters demonstrate that Muslim women in America are resilient, tolerant and compromising despite all the difficulties they encounter as a result of people's misunderstanding. They are well-educated, confident about their faith and proud of their identity as Muslims. However, they do not hold a segregated approach towards life and are ready to contribute to the society in which they live.

While Khadra stands firm in her faith in God and His principles, her subtle and ardent criticism of some impracticalities in Muslim communities encourages criticism from her fellow Muslims. Khadra's rejection of a defensive approach to the understanding of problematic interpretations of the faith, especially those concerning women's rights in Islam, is a brave act. Khadra's progress in her knowledge of Islam and her transformation of the self is also a manifestation of diversified interpretations of Islam. As Ramadan $(2004,9)$ advocates, there is one Islam, but there exists within Islamic principles "an important margin allowed for evolution, transformation and adaptation to various social and cultural 
environments". In this regard, the evolution of Khadra's understanding of Islamic doctrines demonstrates that one cannot label Islamic practices as static or as a reason for social stigmatisation. There are always different approaches and interpretations in the practices of Islam, which allow Muslims to adapt to different social realities. Moreover, the novel does not present an apologetic approach to Islam but rather provides a balanced view regarding social criticism. While the narrative reveals some drawbacks in the Muslim community, criticism of the discriminatory practices of some narrow-minded Americans towards Muslim diasporas, especially towards Muslim women, is also direct and revealing. Khadra's experiences within Muslim communities and within the context of American society provide readers with an impartial approach that helps enhance our understanding of the problems faced by Muslims living in diaspora in America. We recognise that there are problems caused by the Muslims themselves and ones aggravated by religious bigots and racists in the society. Additionally, Khadra's multidimensional approach to life and her open-mindedness encourage Muslims to integrate into their new society while maintaining their religious principles, the worldview necessary for Muslim diasporas to lead fruitful lives in their adopted homelands.

\section{Acknowledgement}

The authors would like to thank International Islamic University Malaysia for funding this research project. This paper is part of a research project titled "Muslim Diaspora in the West: A Postcolonial Study of Selected Post-9/11 Literary Works" (grant number EDW B14-168-1053).

\section{Notes}

1. Fatima Mernissi (1940-2015) was a leading Muslim feminist whose academic works have introduced a new interpretation of Islamic jurisprudence from a feminist perspective. In her first book entitled Beyond the Veil: Male-Female Dynamics in Modern Muslim Society (1975), Mernissi investigates the classical corpus of religious juristic texts, including the hadith, and interprets them from a feminist viewpoint. She points out the religious texts that are misinterpreted and distorted by some male juristtheologians to maintain the patriarchal system. In her later book, The Veil and the Male Elite (first published in French in 1987), Mernissi also explores the historical context of Islamic law and tradition. She asserts that the original message of Prophet Muhammad, which called for gender equality, has been manipulated by later political leaders and religious scholars to preserve their status quo and social influences (see Oxford Islamic Studies Online, Mernissi Fatima at http://www.oxfordislamicstudies. com/article/opr/t236/e0527, accessed September 2017). 
2. On 19 March 2005, Amina Wadud, a professor of Islamic studies at Virginia Commonwealth University and a female Muslim scholar, led a controversial Friday prayer in the US. She addressed the congregation of 80 to 100 men and women attending the service at Synod House at the Cathedral of St. John the Divine, an Anglican Church in Manhattan, emphasising that the purpose of her service was to underscore the fact that men and women are equal under Islam (see Woman Leads Controversial US Prayer, 19 March 2005, http://www.aljazeera.com/archi ve/2005/03/200849145527855944.html, accessed September 2017).

\section{References}

Abdul-Ghafur, S. 2005. Living Islam out loud: American Muslim women speak. Boston: Beacon Press.

Abdurraqib, S. 2006. Hijab scenes: Muslim women, migration, and immigrant Muslim literature. Society for the Study of the Multi-Ethnic Literature of the United States (MELUS) 31(4): 55-70, http://www.jstor.org/stable/30029682 (accessed July 2015).

Ahmed, L. 1992. Women and gender in Islam: Historical roots of a Muslim debate. New Haven: Yale University Press.

Akbar, A.A. 2015. 14 novels about Muslim life that shouldn't be missed. https:// www.buzzfeed.com/ahmedaliakbar/for-you-a-thousand-times-over?utm_term=. psEvMzeqm\#.mjYoYnrbX (accessed June 2016).

Al-Faruqi, L. 1988. Women, Muslim society and Islam. Indianapolis: American Trust Publications.

Ali, A.Y. 1989. The holy Qur'an: Text, translation and commentary. Maryland: Amana Corporation.

Alkarawi, S.T. and Bahar, I.B. 2013. Negotiating liminal identity in Mohja Kahf's The Girl in the Tangerine Scarf. International Journal of Applied Linguistic and English Literature 2(2): 101-106, https://doi.org/10.7575/aiac.ijalel.v.2n.2p.101

Ameri, F. 2012. Veiled experiences: Rewriting women's identities and experiences in contemporary Muslim fictions in English. PhD dissertation, Murdoch University, Australia. http://researchrepository.murdoch.edu.au/10197/ (accessed September 2015).

Ancellin, K. 2009. Hybrid identities of characters in Muslim women's fiction post 9/11. https://trans.revues.org/344 (accessed September 2015).

Badran, M. 2002. Islamic feminism: What's in a name? Al-Ahram Weekly Online (Issue Number 569), http://weekly.ahram.org.eg/2002/569/cu1.htm (accessed July 2015).

2006. Islamic feminism revisited. http://www.countercurrents.org/genbadran100206.htm (accessed July 2015).

2009. Feminism in Islam: Secular and religious convergences. London: Oneworld Publications.

Barlas, A. 2001. Muslim women and sexual oppression: Reading liberation from the Qur'an. Macarlester International 10: 117-146, http://digitalcommons.macalester. edu/cgi/viewcontent.cgi?article=1250\&context (accessed July 2015). 
2012. Asma Barlas: On women, equality and the Qur'an. http://www. wheelercentre.com/notes/6e11e7d0a501 (accessed July 2015).

Basaruddin, A. 2005. Re-defining feminism/s, reimagining faith? Margot Badran on Islamic feminism. Al-Raida XXII (Nos. 109-110, Spring-Summer): 57-65, http://inhouse.lau.edu.lb/iwsaw/raida109-110/EN/p057-088.pdf (accessed June 2015).

Bear, A.L. and Glasgow, J.N. 2010. Negotiating understanding through young adult literature of Muslim cultures. Journal of Adolescent \& Adult Literacy 54(1): 23-32, http://ehis.ebscohost.com/ (accessed June 2015). https://doi.org/10.1598/ JAAL.54.1.3

Bhabha, H.K. 1994. The location of culture. London and New York: Routledge.

Brah, A. 1996. Cartographies of diaspora: Contesting identities. London: Routledge.

Bullock, K. 2003. Rethinking Muslim women and the veil: Challenging historical and modern stereotype. Herndon, VA: International Institute of Islamic Thought.

2011. Hijab and belonging: Canadian Muslim women. In Islam and the veil: Theoretical and regional contexts, eds. T. Gabriel and R. Hannan, 161-202. London and New York: Continuum.

Cesari, J. 2010. Secularization of Islam in Europe. In Muslims in the West after 9/11: Religion, politics and law, ed. J. Cesari, 9-27. London and New York: Routledge.

Chambers, C. 2013. Countering the 'oppressed, kidnapped genre' of Muslim life writing: Yasmin Hai's The Making of Mr. Hai's Daughter and Shelina Zahra Janmohamed's Love in a Headscarf. Life Writing 10(1): 77-96, https://doi.org/10.1080/14484528. 2013.745219

Clyne, I.D. 2003. Muslim women: Some western fictions. In Muslim women in the United Kingdom and beyond, eds. H. Jawad and T. Benn, 19-37. Leiden-Boston: Brill.

Cooke, M. 2001. Women claim Islam: Creating Islamic feminism through literature. New York and London: Routledge.

El Fadl, A. n.d. Fatwa by Dr. El Fadl: On abortion. http://www.scholarofthehouse.org/ fabydrabelfa1.html (accessed November 2015).

Haddad, Y.Y., Smith, J.I. and Moore, K.M. 2006. Muslim women in America: The challenge of Islamic identity today. Oxford and New York: Oxford University Press. https:// doi.org/10.1093/acprof:oso/9780195177831.001.0001

Harb, S. 2012. Arab American women's writing and September 11: Contrapuntality and associative remembering. Society for the Study of the Multi-Ethnic Literature of the United States (MELUS) 37(3): 13-41, https://muse.jhu.edu/article/487904 (accessed June 2015).

Hasan, A. 2011. Democracy, religion and moral values: A road map toward political transformation in Egypt. Foreign Policy Journal, 2 July 2011, http://www. foreignpolicyjournal.com/2011/07/02/democracy-religion-and-moral-values (accessed February 2016).

Hasan, K. 2011. Hijab: A symbol of modesty or seclusion? In Islam and the veil: Theoretical and regional contexts, eds. T. Gabriel and R. Hannan, 115-126. London and New York: Continuum. 
Hashim R.S. and Abdul Manaf. N.F. 2009. Notions of home for diasporic Muslim women writers. European Journal of Social Sciences 9(4): 545-554, http://irep.iium.edu. my/9609/1/ejss_9_4_02.pdf(accessed June 2015).

Heath, J. 2008. Introduction: Invisible and visible spaces. In The veil: Women writers on its history, lore, and politics, ed. H. Jennifer, 1-23. Berkeley Los Angeles and London: University of California Press.

Kahf, M. 2007. The girl in the tangerine scarf. New York: PublicAffairs.

2008. From her royal body the robe was removed: the blessings of the veil and the trauma of forced unveiling in the Middle East. In The veil: Women writers on its history, lore and politics, ed. H. Jennifer, 27-43. Berkeley Los Angeles and London: University of California Press.

Khan, M.I. (ed.). 2012. Rights of women in Islam. London: Koros Press Limited.

Kordvani, A.H. 2002. Hegemonic masculinity, domination, and violence against women. Paper presented at the Expanding Our Horizons: Understanding the Complexities of Violence against Women Conference, 18-22 February 2002, University of Sydney, Australia. http://www.adfvc.unsw.edu.au/Conference (accessed December 2015).

Macfarquhar, N. 2007. She carries weapons; they are called words. New York Times, 12 May 2007, http://www.nytimes.com/2007/05/12/books/12veil.html?pagewanted $=$ all\&_r=0 (accessed June 2015).

Mandaville, P. 2001. Transnational Muslim politics: Reimagining the Umma. London and New York: Routledge. https://doi.org/10.4324/9780203453155

McLeod, J. 2000. Beginning postcolonialism. Manchester and New York: Manchester University Press.

Mernissi, F. 2005. Women in Muslim history: Traditional perspective and new strategies. In Women and Islam: Critical concepts in sociology, vol. 1, ed. M. Haideh, 37-52. London and New York: Routledge.

Mohanty, C.T. 1994. Under Western eyes: Feminist scholarship and colonial discourse. In Colonial discourse and post-colonial theory: A reader, eds. P. Williams and L. Chrisman, 196-220. New York: Columbia University Press.

Naseef, F.U. 1999. Women in Islam: A discourse in rights and obligations. New Delhi: Sterling Publishers Private Limited.

Ramadan, T. 2004. Western Muslims and the future of Islam. Oxford: Oxford University Press.

Smith, J.I. 2010. Islam in America (2nd ed.). New York: Columbia University Press.

Zine, J. 2002. Muslim women and the politics of representation. The American Journal of Islamic Social Studies 19(4): 1-23, http://www.i-epistemology.net/v1/ attachments/691 (accessed July 2015). 